\title{
Wdrażanie innowacji społecznych przez wiejskie organizacje pozarządowe
}

\begin{abstract}
Streszczenie: W działalność podmiotów lokalnej polityki społecznej wpisane jest poszukiwanie rozwiązań dla problemów społecznych. Podejmowane działania w tym zakresie mogą być nietypowe, niestandardowe, alternatywne w stosunku do dotychczas spotykanych w danym kontekście lokalnym. Tak rozumiane innowacje społeczne wdrażają podmioty reprezentujące różne sektory. Każdy z nich ma właściwe sobie cechy, które proces wdrażania tych innowacji mogą wspomagać lub ograniczać. Celem artykułu jest udzielenie odpowiedzi na cztery pytania: 1. Jakie problemy społeczne dostrzegają organizacje pozarządowe z gmin wiejskich województwa, którego mieszkańcy doświadczają szczególnie wielu problemów społecznych? 2. Na rzecz zminimalizowania jakich problemów społecznych działają? 3. Czy wdrażają innowacje społeczne? A jeśli tak, to: 4. Jakiego są one rodzaju? Odpowiedź na powyższe pytania zostanie udzielona na podstawie wyników socjologicznych badań empirycznych zrealizowanych w 2016 r. (z wykorzystaniem techniki wywiadu swobodnego ze standaryzowaną listą poszukiwanych informacji oraz techniki pogłębionego wywiadu swobodnego) na próbie odpowiednio: 108 oraz 4 organizacji pozarządowych z gmin wiejskich województwa lubelskiego. Organizacje te dzielą problemy społeczne na te, których rozwiązywaniem/minimalizowaniem powinny zajmować się instytucje publiczne, oraz te, których rozwiązywaniem mogą się zająć samodzielnie. Bardzo rzadko podejmują aktywność na rzecz rozwiązywania problemów opisywanych w literaturze przedmiotu w kategoriach kluczowych dla przeciwdziałania marginalizacji obszarów wiejskich. Około 3\% ogółu badanych organizacji wdraża innowacje społeczne skoncentrowane przede wszystkim na dostarczaniu zindywidualizowanych usług. Innowacje te są najczęściej krótkotrwale, co ogranicza ich potencjał na rzecz redukowania problemów społecznych.
\end{abstract}

Słowa kluczowe: innowacje społeczne, organizacje pozarządowe, obszary wiejskie, problemy społeczne.

Dr Katarzyna Zajda, Katedra Socjologii Wsi i Miasta, Instytut Socjologii, Uniwersytet Łódzki, 90-214 Łódź, ul. Rewolucji 1905 r. nr 41/43, katarzyna.zajda@uni.lodz.pl. 


\section{Innowacje społeczne i trzeci sektor: wprowadzenie do problematyki}

W ostatnich latach innowacje społeczne stały się terminem bardzo modnym, często używanym zarówno przez teoretyków, jak i praktyków (Jessop i in. 2014, s. 110). Badacze różnie je definiują (Jenson, Harrison 2013), a praktycy czynią wiele, by te definicje zoperacjonalizować i wdrażać m.in. modele, idee, usługi, produkty, które można byłoby określić mianem innowacji społecznych (zob. Ayob, Teasdale, Fagan 2016). Ogromnemu zainteresowaniu tego rodzaju innowacjami sprzyja założenie, że są one czymś dobrym, pożądanym, jako że służą rozwiązywaniu różnorodnych problemów społecznych, w sposób bardziej efektywny od dotychczas znanego i praktykowanego w danym kontekście lokalnym (Nicholls, Simon, Gabriel 2015, s. 2). Zdaniem Bettiny Bock, są one traktowane wręcz jako panaceum na różnego rodzaju problemy sprzyjające społecznej inkluzji i przeciwdziałające nierównościom społecznym (2016, s. 552).

Innowacje społeczne mogą być wdrażane przez różne podmioty lokalnej polityki społecznej (to jest podmioty działające na rzecz rozwiązywania lokalnych problemów społecznych mieszkańców danej jednostki terytorialnej). Podmioty te mogą reprezentować zarówno sektor publiczny (urzędy gmin, ośrodki pomocy społecznej), jak i sektor społeczny ${ }^{1}$ (organizacje pozarządowe).

W literaturze przedmiotu omawia się te cechy sektora publicznego, które ograniczają jego zdolność do wdrażania tego rodzaju innowacji (zob. Oosterlynck i in. 2013, s. 24-26), aczkolwiek zauważa się również, że jego rola we wdrażaniu innowacji społecznych ulega zmianie. Owej zmianie sprzyja wprowadzanie modelu nowego współrządzenia publicznego (New Public Governance), którego cechą jest tworzenie sieci współpracy między sektorami publicznym, społecznym i prywatnym, postrzeganie obywateli jako współtwórców usług publicznych oraz zwiększenie efektywności podejmowanych działań dzięki mobilizacji różnych zasobów i wdrażaniu różnego rodzaju innowacji (Sørensen, Torfing 2015, s. 150, 161-164). Juan-Luis Klein podkreśla, że niewyczerpane źródło inspiracji dla sektora publicznego, które mogą zapoczątkować wdrażanie innowacji społecznych, stanowią organizacje pozarządowe (2014, s. 11) - podmioty aktywne w zakresie rozwiązywania problemów społecznych (również tych dotykających nielicznych zbiorowości), akceptujące (w większym stopniu niż instytucje sektora publicznego) działania nierutynowe, nietypowe, których celem nie jest osiągnięcie zysku finansowego (zob. The Young Foundation 2012, s. 27-32).

1 Sektor gospodarczy jest zainteresowany wdrażaniem innowacji społecznych zdecydowanie rzadziej, jako że ich celem jest rozwiązywanie problemów społecznych, zaspokajanie społecznych potrzeb, a nie generowanie zysku finansowego (Mulgan 2006, s. 146). 
Sektor organizacji pozarządowych jest jednak bardzo zróżnicowany. Jego przedstawicieli różni nie tylko zasięg czy profil działania, ale również m.in. poziom profesjonalizacji i ekonomizacji związany z wielkością i jakością użytkowanych zasobów ludzkich i finansowych, kultura organizacyjna, która może upodabniać je do podmiotów sektora gospodarczego lub sektora publicznego (zob. Kołomycew 2014) czy też zasoby kapitału społecznego. Organizacje pozarządowe można postrzegać jako agentów zmiany w zakresie lokalnej polityki społecznej, choć elementem tej zmiany nie musi być wdrażanie innowacji społecznych.

Przedmiotem niniejszego artykułu jest aktywność wiejskich organizacji pozarządowych w zakresie wdrażania innowacji społecznych. Innowacje społeczne zdefiniowano jako zmiany w obszarze rozwiązywania problemów społecznych polegające na powstawaniu nietypowych praktyk społecznych, alternatywnych w stosunku do dominujących w danym kontekście lokalnym (za jaki uważamy obszar gminy wiejskiej, w której siedzibę posiada organizacja pozarządowa). Praktyki te są oparte na ciągłej refleksyjności podmiotów w nie zaangażowanych i dotyczą zarówno sposobów ich działania na rzecz rozwiązywania problemów społecznych, w tym aktywizowanych przez nie zasobów, jak i relacji między tymi podmiotami.

Ujęć innowacji społecznych jest wiele (zob. Zajda i in. 2016). Noorseha Ayob, Simon Teasdale i Kylie Fagan (2016) podkreślają, że po 2004 r. znacząco zwiększył się odsetek publikacji poświęconych możliwym związkom między innowacjami społecznymi a relacjami społecznymi, ich zmianą, transformacją (również w kontekście lokalnym). Koresponduje to ze wzrostem znaczenia tzw. demokratycznego paradygmatu innowacji społecznych uwypuklającego ich znaczenie dla upodmiotowienia osób wykluczonych społecznie, doświadczających różnego rodzaju problemów społecznych, ich aktywizacji ${ }^{2}$ (Montgomery 2016). W założenia tego paradygmatu wpisuje się aktywność organizacji pozarządowych (jako podmiotów społeczeństwa obywatelskiego) pod warunkiem podejmowania przez nie działań na rzecz upodmiotowienia beneficjentów oferowanego wsparcia, włączania ich $\mathrm{w}$ podejmowane przedsięwzięcia oraz ich planowanie, co sprzyja realizacji zasady upodmiotowienia wpisanej w założenia demokratycznego paradygmatu innowacji społecznych.

Potencjał organizacji pozarządowych do wdrażania innowacji społecznych może różnicować m.in. poziom ich uzależnienia od instytucji publicznych ${ }^{3}$, ekonomizacji,

2 Drugi paradygmat innowacji społecznych autor określił mianem technokratycznego. Tutaj postrzega się je jako narzędzie/instrument tworzący specyficzny rynek rozwiązywania różnorodnych problemów społecznych, zaspokajania potrzeb społecznych (Montgomery 2016, s. 1984).

3 Jej przejawem (zdaniem Agnieszki Rymszy) jest: przejmowanie narzucanych przez instytucje publiczne priorytetów co do wyboru beneficjentów wsparcia czy typu świadczonych usług, obniżanie kosztów 
w literaturze zachodniej określanej również mianem marketyzacji (marketisation) oraz profesjonalizacji, na którą wpływają ilość i jakość zasobów ludzkich takich jak: liczba (również zatrudnionych) członków/ partnerów, ich wykształcenie, poziom kreatywności, kompetencje społeczne, udział w szkoleniach dedykowanych podejmowanej w organizacji działalności. Czynnikiem różnicującym gotowość organizacji pozarządowych do wdrażania innowacji mogą być ponadto postawy ich członków/partnerów względem innowacji społecznych. Odwołując się do klasyfikacji Everetta Rogersa (Rogers 1983, s. 250), również wśród członków organizacji pozarządowych można wyróżnić innowatorów (stanowiących niewielki odsetek każdego społeczeństwa), wczesnych naśladowców innowacji (early adopters) pełniących funkcję liderów opinii społecznej, najczęściej zakorzenionych w danym kontekście lokalnym, wczesną większość (early majority), która adaptuje innowacje często pod wpływem opinii liderów lokalnych, późną większość (late majority), która przyswaja innowacje dość sceptycznie, jednak najczęściej pod presją pozostałych członków sieci społecznej, w której skład wchodzą, i w końcu maruderów (laggards) niechętnych zmianom, skoncentrowanym na przeszłości. Wpływ na aktywność organizacji pozarządowej w zakresie wdrażania innowacji społecznych mogą mieć również zasoby społeczne rozumiane jako potencjał współpracy z innymi podmiotami oraz zasoby finansowe. Znaczący jest także kontekst lokalny (van Dyck, van den Broeck 2013, s. 133), który m.in. kształtuje postrzeganie problemów społecznych przez różne podmioty lokalne i możliwe działania podejmowane w celu ich rozwiązania (czy raczej zredukowania, zminimalizowania).

Proces wdrażania innowacji społecznych (niezależnie od tego, przez kogo jest inicjowany) rozpoczyna diagnoza problemów społecznych (Moulaert i in. 2014, s. 2). Jej konsekwencją jest określenie pewnych zjawisk i procesów mianem problemów społecznych, krytyczna ocena dotychczas podejmowanych działań na rzecz ich zredukowania/zminimalizowania oraz założenie, że dany problem społeczny ma rozwiązanie czy też może być zminimalizowany za pomocą wdrożenia jakiejś innowacji społecznej.

Wśród innowacji społecznych, potencjalnie możliwych do wdrożenia przez organizacje pozarządowe, za Adalbertem Eversem i Benjaminem Ewertem można wyróżnić:

1. Innowacje w sferze usług polegające na ich zindywidualizowaniu, dopasowaniu do potrzeb konkretnych grup odbiorców, ukierunkowane na zwiększenie ich podmiotowości (innovations in services and how they address users).

\footnotetext{
usług w odpowiedzi na wymagania formułowane w postępowaniach przetargowych na realizację zadań publicznych, uleganie presji osiągania szybkich, widocznych i mierzalnych rezultatów działania, ścisłe przestrzeganie wymagań biurokratycznych i budżetów projektowych oraz niepodejmowanie działań ryzykownych (jakimi są innowacje społeczne) (Rymsza 2012, s. 91-92).
} 
2. Innowacje w sferze regulacji i praw dotyczących form pomocy ukierunkowane na ich uruchomienie ad hoc, w nagłych sytuacjach oraz innowacje w zakresie kontaktów socjalnych dotyczących praw i obowiązków osób wspieranych w rozwiązywaniu dotykających ich problemów społecznych (innovations in regulations and rights).

3. Innowacje w sferze zarządzania rozwojem lokalnym wzmacniające kooperację różnych podmiotów, budujące ich koalicje, partnerstwa (innovation in governance).

4. Innowacje dotyczące metod pracy i sposobów jej finansowania polegające np. na łączeniu różnych zasobów wiedzy na rzecz rozwiązywania problemów spolecznych (innovations in methods of working and financing).

5. Innowacje dotyczące całości funkcjonowania polityki społecznej ukierunkowane na osiągnięcie zaangażowania przedstawicieli wszystkich sektorów (zwłaszcza podmiotów lokalnych) w aktywność na ich rzecz (innovations that concern the whole of (local) welfare systems) (Evers, Ewert 2015, s. 112-122).

Wdrożenie różnego rodzaju innowacji społecznych wymaga jednak zasobów kapitału ludzkiego i społecznego. Bock zwraca uwagę, że potrzebne są tutaj kreatywność, wysoki poziom przedsiębiorczości, wykształcenie, jak również zasoby kapitału społecznego (2016, s. 567). Zdaniem autorki niniejszego artykułu, niezmiernie ważne jest również zdefiniowanie przez organizacje pozarządowe pewnych zjawisk i procesów w kategoriach problemów społecznych oraz przeświadczenie, że mogą być one przynajmniej zminimalizowane poprzez ich aktywność. Warunkiem wdrożenia innowacji społecznej jest również refleksyjność tych podmiotów oznaczająca ciągłe monitorowanie podejmowanych działań w kontekście lokalnym, to jest m.in. w kontekście aktywności innych podmiotów (np. organizacji pozarządowych), refleksyjność, która daje podstawę, by sądzić, że podejmowane działanie stanowi (w skali lokalnej) alternatywę dla tego, co już było i jest podejmowane w związku $\mathrm{z}$ rozwiązaniem danego problemu społecznego.

Przedmiotem artykułu jest aktywność wiejskich organizacji pozarządowych w zakresie wdrażania innowacji społecznych. Jego celem jest analiza percepcji problemów społecznych przez ich liderów oraz opis sposobów działania organizacji ze szczególnym uwzględnieniem wdrażanych innowacji społecznych. Jego realizacji miała służyć odpowiedź na cztery pytania badawcze: 1. Jakie problemy społeczne dostrzegają lokalne organizacje pozarządowe $\mathrm{z}$ gmin wiejskich województwa lubelskiego? 2. Na rzecz zminimalizowania jakich problemów społecznych działają? 3. Czy wdrażają innowacje społeczne? A jeśli tak, to: 4. Jakiego są one rodzaju? Na te pytania próbowano odpowiedzieć, realizując projekt badawczy pt.: „Systemy innowacji społecznych na wsi. Perspektywa podmiotów sektora 
publicznego i pozarządowego z województwa lubelskiego"4. W niniejszym artykule zostanie wykorzystana część zebranego materiału badawczego.

\section{Metodologia badań własnych}

\subsection{Charakterystyka obszaru badania}

Wybór województwa lubelskiego, na obszarze którego przeprowadzono badanie, był podyktowany jego specyfiką związaną z wieloma problemami społecznymi, jakich doświadczają jego mieszkańcy. Wielość tych problemów z jednej strony mogła stymulować aktywność organizacji pozarządowych do wdrażania innowacji społecznych, $\mathrm{z}$ drugiej specyfika tych obszarów (związana $\mathrm{z}$ deficytem różnego rodzaju kapitałów pozostających w dyspozycji mieszkańców) mogła tę aktywność ograniczać. Decydując się na jego wybór, kierowano się po pierwsze analizą dokumentu zatytułowanego Strategia Polityki Społecznej Województwa Lubelskiego na lata 2014-2020. Do najpoważniejszych z problemów społecznych mieszkańców województwa zaliczono ubóstwo (podkreślając, że wskaźnik zagrożenia ubóstwem jest tutaj najwyższy w kraju), starzenie się mieszkańców, największy w Polsce udział osób w wieku poprodukcyjnym w liczbie ludności (przy czym 55\% osób starszych zamieszkuje wieś) oraz najwyższy odsetek osób emigrujących (Strategia Polityki Społecznej.... 2013, s. 18, 49). Ponadto zwrócono uwagę na niski poziom aktywności społecznej i obywatelskiej mieszkańców województwa. Drugim czynnikiem decydującym o wyborze tego województwa była samodzielnie przeprowadzona analiza wybranych jego cech świadczących o marginalizacji (posłużono się danymi za 2014 r. z Głównego Urzędu Statystycznego). Na podstawie przeglądu literatury (Bock 2016) zaliczono do nich: odsetek osób bezrobotnych ogółem, saldo migracji na 1000 osób, udział osób, którym przyznano świadczenia społeczne ze względu na ubóstwo wśród ogółu świadczeniobiorców, wskaźniki obciążenia demograficznego, tj. ludność w wieku nieprodukcyjnym na 100 osób w wieku produkcyjnym oraz ludność w wieku poprodukcyjnym na 100 osób w wieku produkcyjnym. Zauważono, że województwo lubelskie (na tle innych polskich województw) cechowało się najniższą pozycją $\mathrm{w}$ rankingu uwzględniającym wymienione zmienne, o czym zadecydowały wartości trzech z pięciu z nich, to jest: saldo migracji na 1000 osób, odsetek osób bezrobotnych ogółem oraz ludność w wieku nieprodukcyjnym na 100 osób w wieku produkcyjnym.

4 Za przeprowadzanie wywiadów swobodnych ze standaryzowaną listą poszukiwanych informacji dziękuję dr Pameli Jeziorskiej-Biel z Wydziału Nauk Geograficznych UŁ, mgr Katarzynie Księżopolskiej (doktorantce z Katedry Metod i Technik Badawczych Instytutu Socjologii UŁ) oraz mgr Zofii Szafrańskiej-Czajce (doktorantce z Katedry Socjologii Polityki i Moralności Instytutu Socjologii UŁ). Zofii Szafrańskiej-Czajce składam również podziękowanie za przeprowadzenie pogłębionych wywiadów swobodnych. 


\subsection{Wykorzystane metoda i techniki badawcze, przyjęte definicje}

Badanie przeprowadzono na próbie organizacji pozarządowych usytuowanych w gminach wiejskich województwa lubelskiego, wykorzystując metodę studium przypadku. Analizowanym przypadkiem było tu ulegające marginalizacji województwo lubelskie. Poddano je analizie z perspektywy aktywności (na rzecz wdrażania innowacji społecznych) organizacji pozarządowych posiadających siedzibę $\mathrm{w}$ gminach wiejskich. Wykorzystano dwie techniki badawcze. Po pierwsze, $\mathrm{z}$ respondentami (prezesami organizacji pozarządowych) przeprowadzono wywiady swobodne ze standaryzowaną listą poszukiwanych informacji. Technikę wybrano ze względu na objęcie badaniem dość zróżnicowanej zbiorowości respondentów, w skład której wchodzili przedstawiciele różnych organizacji pozarządowych, a także kierownicy gminnych ośrodków pomocy społecznej (dla przypomnienia: w artykule prezentujemy tylko część zebranego materiału empirycznego). Technika ta umożliwia zadawanie pytań respondentom w sposób zindywidualizowany, dostosowany do specyfiki danej rozmowy oraz ich możliwości poznawczych, oferując jednocześnie standaryzację w zakresie wykazu poszukiwanych informacji (Przybyłowska 1978). Za pomocą tej techniki poszukiwano informacji na temat: 1) Problemów społecznych, w opinii respondentów najbardziej dotkliwych w gminie, na obszarze której usytuowana jest ich organizacja; 2) Problemów społecznych, na rzecz których rozwiązania/zminimalizowania działa reprezentowana przez nich organizacja. Dążono również do poznania opinii respondentów na temat tego, czy organizacja pozarządowa powinna być gotowa do podejmowania działań niestandardowych, nieschematycznych, innych niż dotychczas realizowane w skali lokalnej, jeśli ma przekonanie, że mogą one pomóc rozwiązać lub zminimalizować jakiś lokalny problem społeczny.

Po drugie, z prezesami organizacji deklarujących wdrażanie innowacji społecznych przeprowadzono pogłębione wywiady swobodne. Respondentów proszono o opis wdrażanej innowacji społecznej wraz z uzasadnieniem, na czym polega jej nietypowość w kontekście działań innych organizacji pozarządowych funkcjonujących na obszarze gminy, oraz wskazaniem problemu społecznego, na który odpowiada. Wywiady przeprowadzono z czterema respondentami (trwały one od 23 do 64 minut).

Innowacje społeczne - co jeszcze raz warto podkreślić - zdefiniowano jako zmiany wprowadzane w obszarze rozwiązywania problemów społecznych, polegające na powstawaniu alternatywnych, w stosunku do dominujących, praktyk społecznych.

Problemy społeczne za Johnem Alessio określono jako warunki, które przez jednostki lub zbiorowości są definiowane w kategoriach problemu, zostały wywołane 
przez co najmniej jedną społeczną przyczynę, posiadają co najmniej jedną społeczną konsekwencję i co najmniej jedno rozwiązanie (2011, s. 3).

\subsection{Dobór i charakterystyka próby badawczej}

Badanie, którego efekty zostaną zaprezentowane z niniejszym artykule, zrealizowano w okresie październik-grudzień 2016 r., posługując się bazą organizacji pozarządowych zakupioną od Urzędu Statystycznego w Lublinie ${ }^{5}$. Tworząc operat do badania, uwzględniono tylko te organizacje, które podały do publicznej wiadomości numer telefonu do swojej siedziby. Aktywny numer telefonu był warunkiem niezbędnym do zrealizowania wywiadów swobodnych ze standaryzowaną listą poszukiwanych informacji $z$ ich prezesami. Stworzony operat liczył 580 organizacji. Ze wszystkimi z uwzględnionych ( $w$ celu umówienia i zrealizowania wywiadu) podjęto próbę kontaktu telefonicznego (to jest co najmniej trzykrotną próbę dodzwonienia się w trzech różnych dniach tygodnia, w różnych godzinach, również wieczornych). Aż 303 uwzględnione w bazie numery telefonów były błędne, to jest albo ankieterki dodzwaniały się do innych osób niemających żadnego związku z organizacjami pozarządowymi, albo numery tych telefonów w ogóle nie były aktywne. Operat zmniejszono zatem do 277 organizacji. W okresie badania trzem ankieterkom udało się dodzwonić do 200, z czego 108 prezesów zgodziło się wziąć w nich udział (ze wszystkimi przeprowadzono wywiady swobodne ze standaryzowaną listą poszukiwanych informacji) ${ }^{6}$. $\mathrm{Z}$ czterema $\mathrm{z}$ nich przeprowadzono

5 Ze zbiorowości tych organizacji wyłączono: koła gospodyń wiejskich, ochotnicze straże pożarne, kluby sportowe, stowarzyszenia hodowców (np. koni, trzody chlewnej), kluby jeździeckie, grupy ratownictwa specjalnego, organizacje działające na rzecz zwierząt i ekologii, zespoły ludowe, w tym zespoły pieśni i tańca, stowarzyszenia przewoźników, stowarzyszenia agroturystyczne, stowarzyszenia i związki wędkarskie, stowarzyszenia ogrodowe, stowarzyszenia orkiestr dętych, towarzystwa archeologiczne, stowarzyszenia miłośników przyrody, stowarzyszenia ośrodków rekreacyjnych, bractwa rycerskie, stowarzyszenia motocyklistów i komitety społeczne.

6 Mimo ogromnego wysiłku włożonego w budowę „realnego” operatu nie udało się spełnić warunków przeprowadzenia badania na reprezentatywnej próbie organizacji pozarządowych usytuowanych na obszarze gmin wiejskich województwa lubelskiego, co uniemożliwia uogólnienie wniosków z próby na populację. Bardzo wiele z organizacji uwzględnionych w bazach Urzędu Statystycznego w Lublinie (jak również innych podobnych urzędów) po prostu zaprzestało działalności, nie informując o tym fakcie urzędu, lub zawiesiło działalność czy to do czasu, kiedy możliwe będą do pozyskania jakieś środki finansowe, czy też odłożyło decyzję o zaprzestaniu działalności na przyszłość. Prezesi tych organizacji najczęściej nie zgadzali się na udział w wywiadzie, tłumacząc to tym, że organizacja (jak to bardzo często określali) „pozostaje uśpiona”. Wywiady udało się przeprowadzić z prezesami organizacji, które były aktywne chociażby w tym znaczeniu, że reprezentująca je osoba (prezes) odbierała telefon „służbowy”. Problemy korzystania z baz organizacji pozarządowych pozostających w dyspozycji Głównego Urzędu Statystycznego oraz Stowarzyszenia Klon/ Jawor są od lat omawiane w literaturze przedmiotu (Bednarek-Szczepańska 2011, s. 219; Działek 2014, s. 182), niemniej bazy te nadal mają liczne wady, co jest związane ze stosunkiem osób reprezentujących 
dodatkowo pogłębione wywiady swobodne. Były to osoby, które zadeklarowały, że ich organizacja wdraża lub wdrożyła innowację społeczną w gminie, na obszarze której jest usytuowana.

W badanej populacji nie znalazły się osoby do 24 roku życia, osób w wieku 25-34 lata było zaledwie 9\%. Prezesami badanych lubelskich organizacji pozarządowych usytuowanych na obszarze gmin wiejskich rzadko były również osoby powyżej 65 roku życia (stanowiły one zaledwie ok. 5\% ogółu respondentów). Wśród badanych znajdowały się przede wszystkim osoby w wieku 35-44 lata (stanowiące 36,7\% ogółu badanych) oraz 45-54 lata (31,2\%).

Zdecydowana większość respondentów cechowała się wykształceniem wyższym (64,2\% badanych) lub średnim (33\% badanych). Nieco więcej niż 8 na 10 badanych (dokładnie $84 \%$ ) było aktywnych zawodowo. Wśród pozostałych dominowały osoby będące na emeryturze lub korzystające $\mathrm{z}$ renty.

Respondenci byli zrzeszeni w organizacjach działających na rzecz rozwiązywania różnych problemów społecznych (o czym szerzej w kolejnej części pracy). Były to organizacje o dość wysokim stopniu sprofesjonalizowania mierzonym takimi wskaźnikami jak: 1) uczestnictwo członków/pracowników w szkoleniach związanych z podejmowanymi działaniami - aż 3/4 badanych stwierdziło, że w $2015 \mathrm{r}$. członkowie/pracownicy brali w nich udział, 2) planowanie inwestycji w szkolenia członków/pracowników w najbliższym roku - 70\% badanych zadeklarowało, że taka inwestycja będzie również podjęta w 2017 r., 3) zatrudnianie pracowników prawie $1 / 3$ ogółu respondentów zadeklarowała, że organizacja w zeszłym roku (tj. 2015) zatrudniała pracowników. Co więcej ponad połowa respondentów zadeklarowała, że sposobem prowadzenia działalności statutowej przez organizację są działania ciągłe.

Respondenci biorący udział w pogłębionych wywiadach swobodnych cechowali się wykształceniem wyższym, wszyscy byli aktywni zawodowo. Organizacje, do których należeli, prowadziły działalność ciągłą, zatrudniając personel.

\section{Organizacja pozarządowe a innowacje społeczne: wyniki badań}

3.1. Problemy społeczne mieszkańców gmin wiejskich w opinii liderów badanych organizacji pozarządowych

Podejmując próbę określenia problemów społecznych w opinii respondentów najbardziej dotkliwych dla osób zamieszkujących gminę, na obszarze której usytuowana jest dana organizacja, poproszono ich o konkretne wskazania. Pytanie miało

organizacje pozarządowe do aktualizowania ich danych lub informowania tych instytucji o fakcie zaprzestania działalności. 
formę otwartą dla respondenta i zamkniętą dla ankietera ${ }^{7}$. Zgodnie z zasadami techniki wywiadu swobodnego ze standaryzowaną listą poszukiwanych informacji ankieterzy wypowiedzi przyporządkowali do jednej z 13 wyróżnionych kategorii: 1) bieda, ubóstwo, 2) bezrobocie, 3) alkoholizm i inne uzależnienia, 4) przemoc domowa, 5) rozpad rodzin, 6) niedożywienie dzieci, 7) brak zorganizowanych form spędzania czasu wolnego dzieci i młodzieży, 8) niewielka gotowość mieszkańców do pomagania sobie nawzajem, 9) niewielkie zainteresowanie mieszkańców sprawami lokalnymi, 10) wykluczenie edukacyjne dzieci, bariery dostępu do edukacji, 11) migracje, 12) niepełnosprawność, 13) starzenie się społeczeństwa ${ }^{8}$.

W świetle opinii badanych najważniejszym problemem społecznym, z jakim zmagają się mieszkańcy gmin, na obszarze których ulokowane są reprezentowane przez nich organizacje pozarządowe, jest bezrobocie. Takiego zdania było 66\% ogółu respondentów. Inne problemy społeczne (ich zdaniem) były mniej znaczące. Co trzeci badany zaliczył do nich alkoholizm i inne uzależnienia oraz ograniczone możliwości dzieci i młodzieży w zakresie spędzania czasu wolnego w zorganizowanych formach pozaszkolnych. Jeden na pięciu badanych wymienił także biedę, ubóstwo oraz niewielkie zainteresowanie mieszkańców sprawami gminy. Pojedyncze osoby do najważniejszych problemów dotykających mieszkańców gminy zaliczyły przemoc domową, rozpad rodzin, niedożywienie dzieci, wykluczenie edukacyjne dzieci i młodzieży, migracje oraz wskazały na niską jakość opieki nad osobami niepełnosprawnymi i starszymi. Respondentów proszono również o określenie problemu, na rzecz rozwiązania/zminimalizowania którego działa ich organizacja.

Badane organizacje pozarządowe najczęściej działały na rzecz rozwiązywania problemu deficytu zorganizowanych form spędzania czasu wolnego przez dzieci i młodzież, który został wskazany jako jeden z kluczowych dla mieszkańców gminy. Deklarację, że aktywność w tym zakresie stanowi główny profil działalności organizacji, złożyło 50\% ogółu respondentów. Natomiast prawie 35\% ogółu badanych organizacji działało na rzecz przeciwdziałania wykluczeniu edukacyjnemu dzieci i młodzieży, którego wcześniej respondenci nie wymieniali jako jednego z najważniejszych problemów dotykających mieszkańców gminy. Badane organizacje zajmowały się również udzielaniem pomocy osobom starszym (tak profil

7 W celu pozyskania informacji od respondenta ankieter dopasowywał sposób zadawania pytania do konkretnego wywiadu, czasami zadając kilka podobnych pytań, by uzyskać poszukiwaną informację. Dla przykładu respondentom zadawano pytanie: „Jakie problemy społeczne są najbardziej dotkliwe w gminie, na obszarze której usytuowana jest organizacja, do której Pan/Pani należy?” lub też „Ludzie mieszkający na obszarze gminy, gdzie działa organizacja, zmagają się z różnymi problemami społecznymi. Jakie z nich są Pana/Pani zdaniem najbardziej dotkliwe?". Ankieterzy prowadzili wywiad tak, by liczba wymienianych problemów nie była większa niż trzy. W pytaniu podkreślano zatem określenie „najbardziej dotkliwe”.

8 Kategoria „starzenie się społeczeństwa” powstała po analizie odpowiedzi wpisujących się w kategorię „inne, jakie?”. 
działalności swojej organizacji zaklasyfikowało 14\% ogółu badanych), nieliczne wskazały na aktywność w zakresie rozwiązywania problemu alkoholizmu i innych uzależnień, minimalizowania skutków biedy i ubóstwa, bezrobocia oraz niepełnosprawności. Fakt, że respondenci relatywnie rzadko wśród problemów, na rzecz których działają reprezentowane przez nich organizacje, wymienili bezrobocie, alkoholizm, biedę i ubóstwo (a więc problemy określane mianem najdotkliwszych dla mieszkańców), wynikał z przypisywania głównej roli w ich rozwiązywaniu nie organizacjom pozarządowym, a instytucjom samorządowym (przede wszystkim gminnemu ośrodkowi pomocy społecznej) jako jednostkom sprofesjonalizowanym, dysponujących zasobami finansowymi. Jak wskazywali badani, organizacjom pozarządowym, w których aktywność najczęściej są zaangażowani tzw. społecznicy, wolontariusze „łatwiej” jest zorganizować jakąś formę spędzania czasu wolnego dla dzieci i młodzieży niż świadczyć usługi, których odbiorcami są osoby uzależnione od alkoholu (typu warsztaty terapeutyczne) wymagające profesjonalnej wiedzy.

Prezesi badanych organizacji pozarządowych wśród problemów społecznych dotykających mieszkańców gmin, na obszarze których prowadzą swoją działalność, bardzo rzadko dostrzegali depopulację czy niepełnosprawność zidentyfikowane w Strategii Polityki Społecznej Województwa Lubelskiego na lata 2014-2020. Zauważane problemy dzielili na te, których rozwiązania, minimalizowania mogą się podjąć samodzielnie, i im poświęcali swoją działalność (należały do nich przede wszystkim brak zorganizowanych form spędzania czasu wolnego dzieci i młodzieży), oraz te, których rozwiązywaniem mogą (a wręcz powinny) zająć się instytucje publiczne, bardziej sprofesjonalizowane i dysponujące zasobami finansowymi, które mogą przeznaczyć na ten cel.

Betina Bock, krytycznie ustosunkowując się do traktowania innowacji społecznych jako panaceum na różnego rodzaju problemy społeczne, wspomina o tym, że do najważniejszych z nich na wiejskich obszarach należą bieda, ubóstwo, depopulacja, starzenie się mieszkańców (2016, s. 558). Z przeprowadzonych badań wynika, że czynnikiem ograniczającym aktywność organizacji pozarządowych na rzecz wdrażania innowacji społecznych im poświęconych jest fakt, iż większość z nich nie postrzega tych zjawisk i procesów w kategorii problemów, na rzecz których rozwiązania/zminimalizowania mogą i chcą podejmować aktywność.

\subsection{Aktywność badanych NGO w zakresie wdrażania innowacji społecznych oraz ich typy}

W celu określenia, czy dana organizacja pozarządowa wdraża innowacje społeczne, dążono do poznania opinii ich prezesów na temat tego, czy jest ona gotowa do podejmowania działań niestandardowych, nieschematycznych, innych niż 
dotychczas podejmowane w skali lokalnej, jeśli ma przekonanie, że mogą one pomóc rozwiązać, zminimalizować jakiś lokalny problem społeczny. Jeśli odpowiedź respondenta była twierdząca, proszono o wskazanie, czy takie działanie było lub jest aktualnie podejmowane przez organizację, którą reprezentuje, oraz o jego opis wraz z uzasadnieniem, na czym polega owa niestandardowość/nieschematyczność w kontekście działań innych organizacji pozarządowych funkcjonujących na obszarze gminy. Warunkiem uznania danego działania za przykład innowacji społecznej było, po pierwsze, powiązanie tego działania z jakimś problemem społecznym, po drugie, odniesienie go do aktywności innych organizacji pozarządowych z obszaru danej gminy w celu wykazania, że działanie to stanowi alternatywę dla ich aktywności, tj. jest niestandardowe, nieschematyczne w danym kontekście lokalnym (na obszarze gminy). Za innowacje społeczne uznano te działania, które spełniały te dwa kryteria.

Założono, że organizacje pozarządowe działające na obszarze gmin wiejskich relatywnie łatwo mogą pozyskać informacje na temat aktywności podejmowanej przez inne usytuowane tam organizacje pozarządowe, których zazwyczaj jest nie więcej niż kilka. Podmioty należące do tego samego sektora, których aktywność jest regulowana tymi samymi przepisami, podejmują aktywność w podobnych warunkach instytucjonalnych. Łatwiej jest zatem porównać przedsięwzięcia realizowane przez różne organizacje pozarządowe (nawet te, które między sobą bardzo się różnią w zakresie poziomu profesjonalizacji czy ekonomizacji/ marketyzacji) niż przedsięwzięcia wdrażane przez przedstawicieli różnych sektorów ${ }^{9}$.

Gotowość do wdrażania innowacji społecznych zadeklarowali prawie wszyscy respondenci (98\%), jednak tylko czterech wskazało, że podejmowało lub podejmuje działania, które, ich zdaniem, stanowiły przykłady innowacji społecznych. Jeden przykład działania wykluczono z analizy, jako że w opinii respondentki na obszarze gminy prowadzi działalność tylko jedna organizacja pozarządowa. Zatem zebrany materiał wskazywał, że innowacje społeczne były wdrożone przez trzy ze 108 badanych organizacji pozarządowych (co stanowi 2,8\% ich ogółu).

Przypadek pierwszy. Innowacja społeczna została wdrożona przez Stowarzyszenie Rodzicielstwa Zastępczego „Jedno Serce” działające na rzecz wsparcia dzieci

9 Założono zatem, że podejmowanie działalności określanej mianem nieschematycznej, niestandardowej, nietypowej w skali gminy wymaga wiedzy dotyczącej typowych sposobów rozwiązywania jakiegoś problemu społecznego lub jego minimalizowania. $Z$ tego względu nie brano pod uwagę przypadków działań podejmowanych przez podmioty, których przedstawiciele twierdzili, że na obszarze gminy nie działają inne organizacje pozarządowe. Porównywanie tych deklaracji z danymi zastanymi nie miało sensu ze względu na ich jakość (o czym wspomniano w części niniejszego artykułu, w której omówiono sposób doboru próby). Nie rozstrzygamy zatem, czy innowacje społeczne mogą być wdrażane w gminach wiejskich, w których aktywna jest tylko jedna organizacja pozarządowa. Taka sytuacja wykracza bowiem poza przyjęty w projekcie model analizy. 
i młodzieży przebywających w rodzinach zastępczych. Stowarzyszenie niweluje skutki problemów społecznych, które doprowadziły do umieszczenia dzieci w rodzinach zastępczych, takich jak m.in. alkoholizm i inne uzależnienia, rozpad rodzin, bieda i ubóstwo. Koncentruje się na przeciwdziałaniu wykluczeniu społecznemu dzieci i młodzieży przebywających pod opieką rodzin zastępczych. Dostarcza zindywidualizowanych usług (najczęściej w formie szkoleń, warsztatów) ukierunkowanych na podniesienie poczucia wartości siebie dzieci i młodzieży, wzrost ich samooceny, wspieranie ich rozwoju społecznego, upodmiotowienie. Wsparciem stowarzyszenia są również obejmowani rodzice zastępczy oraz nauczyciele tych osób. Stowarzyszenie jest członkiem Koalicji na Rzecz Rodziny i Pieczy Zastępczej, która, jak to określił respondent, „bierze udział w pracach legislacyjnych w Sejmie i Senacie". Podanym przykładem innowacji społecznej jest program stypendialny dla podopiecznych stowarzyszenia. Badany opisał go w następujący sposób: „Jako jedyny program w Polsce obejmuje młodzież, głównie z pieczy zastępczej. Regulamin tego programu stypendialnego pozwala nam objąć programem młodzież, niezależnie od wyników w nauce. Objęte są nim dzieci w wieku gimnazjalnym i powyżej, które podejmują wysiłek w celu podniesienia średniej ocen (powyżej 4,5). Ten program uruchomiliśmy we współpracy z Fundacją im. Stefana Batorego. Przedstawiliśmy nasz pomysł, a oni zaprosili nas do współpracy, twierdząc, że nie spotkali się z tego typu stypendium. Ocenili to jako coś, co może przynosić wymierny efekt i przynosi. To jest nasz autorski pomysł. I na moją wiedzę, na dzień dzisiejszy w Polsce nie ma takie drugiego".

Przypadek drugi. Innowacja społeczna została wdrożona przez Fundację Likejon obejmującą wsparciem osoby niesłyszące i głuchonieme. Wprowadziła ona usługę tłumacza migowego $w$ formie on-line. $O$ jej cechach respondent opowiadał w następujący sposób: „To jest w ramach naszej odpłatnej działalności statutowej, bo to jest na takiej zasadzie, że my świadczymy usługę dyżurnego tłumacza on-line, a po drugiej stronie w każdym urzędzie czy innej instytucji jest osoba niesłysząca, którą może skorzystać z pomocy tłumacza w czasie rzeczywistym. To jest trójstronna konferencja. Urzędnik wykonuje połączenie do nas, my widzimy petenta, tłumaczymy, co on chce załatwić, i przekazujemy mu informację od urzędnika. $\mathrm{Na}$ takiej zasadzie to działa. [...] Odpłatność za oferowaną usługę jest pobierana $\mathrm{w}$ formie abonamentu, czyli taka instytucja bierze od nas taki wideotelefon. Nie płaci za niego, tylko za abonament, za gotowość do podjęcia tłumaczenia. Tłumacz jest cały czas dostępny na dyżurze". Usługa jest dostarczana do instytucji, które wyraziły nią zainteresowanie. Takich instytucji, w opinii respondenta, jest jednak niewiele. Ich przedstawiciele nie widzą potrzeby korzystania z niej w sytuacji, kiedy odsetek osób niesłyszących, głuchoniemych, z którymi się spotykają, jest niewielki, a dodatkowo te osoby przychodzą do urzędu z inną osobą, która okazuje się pomocna 
w komunikacji z urzędnikiem. Jak zauważył respondent: „Tu nie ułatwiają sprawy sami niesłyszący, bo nie pokazują się sami, że chcą coś załatwić, tylko zawsze idą z jakimś tłumaczem. I to jest takie przyzwyczajenie urzędów, że każdy musi sobie coś załatwić żeby móc sobie coś załatwić. A każdy urząd powinien mieć taki dostęp, żeby każdy mógł sobie coś załatwić, żeby osoba niesłysząca mogła przyjść i załatwić sprawę jak zwykła osoba słysząca. A tak nie jest. [...] Najczęściej osoby niesłyszące przychodzą z kimś z rodziny".

Przypadek trzeci. Innowacja społeczna została wdrożona przez Stowarzyszenie Wzajemnej Pomocy „Nasz Dom” w Modryniu funkcjonujące przy środowiskowym domu samopomocy. Obejmuje ono wsparciem przede wszystkim jego podopiecznych, to jest głównie osoby niepełnosprawne oraz z różnych względów „nieporadne życiowo”, ale również innych mieszkańców gminy (przede wszystkim osoby bezrobotne, doświadczające biedy i ubóstwa). O innowacji społecznej respondentka opowiadała w następujący sposób: „Byliśmy pierwszą jednostką, pierwszą organizacją, która w całym powiecie zajęła się dystrybucją żywności. Dzięki temu, mieszkańcy gminy Mircze dostali bardzo wysokiej jakości produkty żywnościowe. Praktycznie od 5 lat dostają ogromne paczki żywnościowe w okresie przedświątecznym, które wystarczają na 3-4 miesiące później. Weszliśmy też we współpracę z sadownikami spod Sandomierza, którzy nas częstowali ogromną ilością jabłek i my te jabłka też tutaj dystrybuowaliśmy na teren całej naszej gminy. I nikt w całym powiecie, chociaż organizacje mają do tego prawo i mogą się tym zajmować, żadna organizacja się tym nie zajmowała - tylko moja. Tylko ja namawiałam, rozmawiałam i namówiłam jeszcze dwie, które przystąpiły do tego dopiero w ubiegłym roku”.

Wskazane przykłady innowacji społecznych były wdrażane przez organizacje, które funkcjonują od co najmniej kilku lat. Co warto podkreślić, były jedynymi innowacjami społecznymi, które udało się im zrealizować. Każda z nich odpowiadała na jakiś problem społeczny, który dotyczył osób zagrożonych wykluczeniem społecznym z powodu trudnej sytuacji rodzinnej, niepełnosprawności, biedy, ubóstwa. Dwa pierwsze przykłady dotyczyły dostarczenia usług zindywidualizowanych, dostosowanych do potrzeb konkretnych grup odbiorców. Ich elementem było również upodmiotowienie. Trzeci przykład również dotyczył usługi, choć trudno określić ją mianem zindywidualizowanej oraz ukierunkowanej na zwiększenie podmiotowości grupy wsparcia. Pytaniem pozostaje, czy zaprezentowane sposoby działania (określone mianem innowacji społecznej) są w stanie zmienić (choćby w jakimś zakresie) sytuację osób doświadczających wskazanych problemów społecznych, czy też szerzej mogą minimalizować różne wymiary marginalizacji obszarów wiejskich?

Problem $z$ innowacjami społecznymi polega na tym, że ich wdrożeniu towarzyszy założenie, że są one bardziej efektywne w rozwiązywaniu (minimalizowaniu) jakiegoś problemu społecznego niż inne podejmowane w tym celu działania. 
Zasadność tego założenia można zweryfikować dopiero po jakimś czasie. W zależności od problemu ten czas jest krótszy lub dłuższy. Można wyobrazić sobie sposoby ewaluacji opisanych działań podejmowanych przez organizacje pozarządowe, przy czym trudniej jest stwierdzić ich wpływ na sytuację młodych osób, które znalazły się w trudnej sytuacji na skutek rozpadu rodziny czy też różnych dysfunkcjonalnych zachowań swoich opiekunów, łatwiej na sytuację materialną osób biednych i ubogich otrzymujących paczki żywnościowe. Wydaje się, że wskazane innowacje społeczne stanowią przykład obietnicy złożonej przez organizacje je wdrażające osobom obejmowanym wsparciem. W jakimś zakresie odpowiadają na problem biedy i ubóstwa czy społeczne konsekwencje niepełnosprawności wskazane w Strategii Polityki Społecznej Województwa Lubelskiego na lata 2014-2020 jako najdotkliwsze problemy społecznego tego obszaru. Jeśli jednak nie będą długofalowym działaniem, to siła ich oddziaływania na rzecz minimalizowania wybranych problemów społecznych obszarów zmarginalizowanych będzie (w najlepszym przypadku) niewielka.

\section{Podsumowanie}

Innowacje społeczne stanowią przykład idei nośnej społecznie, która w dość krótkim czasie zyskała zwolenników nie tylko wśród teoretyków, ale i praktyków gotowych inwestować w jej rozwój niemałe środki finansowe (jeśli spojrzeć chociażby na wielkość grantów przeznaczonych na badanie i wdrażanie innowacji społecznych dystrybuowanych przez Komisję Europejską tylko w ramach HORYZONTU 2020). Idea ta doczekała się również swoich krytyków, którzy wskazują na jej liczne mankamenty. Oprócz dość oczywistych problemów związanych z definiowaniem i opercjonalizowaniem innowacji społecznych podkreśla się iluzję pewnych założeń leżących u jej podstaw, dotyczących refleksyjności (rozumianej jako krytyczny ogląd rzeczywiści społecznej oraz podejmowanych działań) jednostek i różnych podmiotów społecznych. Jak wskazywał już Everett Rogers, niewiele osób jest skłonnych do tworzenia innowacji. Większość z nas posługuje się utrwalonymi schematami poznawczymi, a nawet (czego już dawno dowiedli psychologowie społeczni) dopasowuje ocenę i ogląd rzeczywistości społecznej do dostępnych sobie schematów poznawczych. Iluzją jest również oczekiwanie permanentnie krytycznego stosunku różnego rodzaju instytucji i organizacji do podejmowanych przez siebie działań, zwłaszcza w czasach biurokratyzacji przy rozliczaniu pozyskiwanych źródeł finansowych, uszczegółowienia wskaźników ich rezultatów i raportowania niemal każdej zmiany w realizowanym projekcie.

W niniejszym artykule wśród zmiennych istotnych dla wdrażania innowacji społecznych zwrócono uwagę na definiowanie przez organizacje pozarządowe 
zjawisk i procesów w kategorii problemów społecznych, na rzecz których mogą one działać. Konstruktywistyczne ujęcie problemów społecznych (w myśl którego zjawisko czy proces musi być zdefiniowane jako problem społeczny, aby nim rzeczywiście się stało) jest pomocne w ocenie roli, jaką organizacje pozarządowe mogą odegrać w niwelowaniu problemów społecznych obszarów zmarginalizowanych za pomocą innowacji społecznych. Przedstawiciele badanych organizacji pozarządowych nie dostrzegali problemu depopulacji swoich wsi, z związku z czym nie należy oczekiwać, że będą wdrażać innowacje społeczne poświęcone temu problemowi. Dzielili problemy społeczne na te „poważniejsze”, których rozwiązywanie/minimalizowanie należy do obowiązków instytucji publicznych, i te mniej dolegliwe, na rzecz których mogą samodzielnie podejmować aktywność.

Innowacje społeczne na obszarach wiejskich, których mieszkańcy doświadczają wielu problemów społecznych, co prawda rzadko, ale jednak się pojawiają. Dotyczą one przede wszystkim sfery zindywidualizowanych usług dopasowanych do potrzeb konkretnych grup odbiorców, choć nie zawsze ich celem jest ich upodmiotowienie.

Zatem innowacje społeczne mogą pojawić się w każdym kontekście lokalnym i być wdrażane przez przedstawicieli różnych sektorów, ale na zasadzie wyjątku, a nie powszechnej praktyki. Problemem jest ocena ich długofalowego oddziaływania na choćby wybrane problemy społeczne obszarów wiejskich, a tym samym zweryfikowanie ich efektywności jako jednego $\mathrm{z}$ towarzyszących ich wdrażaniu założeń.

\section{Bibliografia}

Alessio J. (2011). Social Problems and Inequality. Ashgate: Routledge.

Ayob N., Teasdale S., Fagan K. (2016). How social innovation 'came to be': Tracing the evolution of a contested concept. Journal of Social Policy, 45 (4), 635-653.

Bednarek-Szczepańska M. (2011). Organizacje pozarządowe na obszarach pozametropolitarnych na przykładzie wybranych regionów. Studia Obszarów Wiejskich, 26, 217-231.

Bock B. (2016). Rural Marginalisation and the role of social innovation; A turn towards nexogenous development and rural reconnection. Sociologia Ruralis, 56 (4), 552-573.

Bock B., Kovacs K., Shucksmith M. (2015). Changing social characteristics, patterns of inequality and exclusion. W: A.K. Copus, P. De Lima (red.). Territorial Cohesion in Rural Europe (s. 193-211). London-New York: Routledge.

Dart R. (2004). The legitimacy of social enterprise. Nonprofit Management and Leadership, $14(4), 411-424$.

Dyck B. van, Broeck P. van den (2013). Social innovation: A territorial process. W: F. Moulaert, D. MacCallum, A. Mehmood, A. Hamdouch (red.). The International Handbook on Social Innovation (s. 131-141). Cheltenham-Northampton MA: Edward Elgar. 
Działek J. (2014). Is social capital useful for explaining economic development in Polish regions? Geografiska Annaler; Series B, Human Geography, 96 (2), 177-193.

Eikenberry A.M. (2009). Refusing the market: A democratic discourse for voluntary and non profit organizations. Nonprofit and Voluntary Sector Quarterly, 38 (4), 582-596.

Evers A., Ewert B. (2015). Social innovations for social cohesion. W: A. Nicholls, J. Simon, M. Gabriel (red.). New Frontiers in Social Innovation Research (s. 107-127). UK: Palgrave Macmillan.

Han J. (2017). Social marketisation and policy influence of third sector organisations: Evidence from the UK. Voluntas, 28, 1209-1225.

Jenson J., Harrison D. (2013). Social Innovation Research in the European Union. Approachces, Findings and Future Dirctions. Policy Review. Luxemburg: European Union.

Jessop B., Moulaert F., Hulgard L., Hamdouch A. (2014). Social innovation research: A new stage in innovation analysis? W: F. Moulaert, D. MacCallum, A. Mehmood, A. Hamdouch (red.). The International Handbook on Social Innovation (s. 110-130). UK, USA: Edward Elgar.

Klein J.-L. (2014). Introduction: Social innovation at the crossroads between science, economy and society. W: F. Moulaert, D. MacCallum, A. Mehmood, A. Hamdouch (red.). The International Handbook on Social Innovation (s. 9-12). UK, USA: Edward Elgar.

Kołomycew A. (2014). Organizacje społeczne w strukturze partnerstw międzysektorowych w województwie podkarpackim. Profesjonalizacja i formalizacja jako konsekwencja zmian sektora społecznego. W: A. Kołomycew, B. Kotarba (red.). Partnerstwa w sferze publicznej (s. 137-151). Warszawa: Wydawnictwo Naukowe Scholar.

Montgomery T. (2016). Are social innovation paradigms incommensurable? Voluntas, 27, 1979-2000.

Moulaert F., MacCallum D., Mehmood A., Hamdouch A. (2014). General introdution: The return of social innovation as a scientific concept and a social practice. w: F. Moulaert, D. MacCallum, A. Mehmood, A. Hamdouch (red.). The International Handbook on Social Innovation (s. 1-8). UK, USA: Edward Elgar.

Mulgan G. (2006). The process of social innovation. Innovations: Technology, Governance, Globalization, 1 (2), 145-162.

Nicholls A., Simon J., Gabriel M. (2015). Introduction: Dimensions of social innovations. W: A. Nicholls, J. Simon, M. Gabriel (red.). New Frontiers in Social Innovation Research (s. 1-28). UK: Palgrave Macmillan.

Nickel P.M., Eikenberry A.M. (2009). A critique of the discourse of marketized philanthropy. American Behavioral Scientist, 52 (7), 974-989.

Oosterlynck S., Kazepov Y., Novy A., Cools P., Barberis E., Wukovitsch F., Sarius T., Leubolt B. (2013). The butterfly and the elephant: Local social innovation, the welfare state and new poverty dynamics. ImPRovE Discussion Paper No. 13/03. Herman Deleeck Centre for Social Policy. Antwerp: University of Antwerp.

Przybyłowska I. (1978). Wywiad swobodny ze standaryzowaną listą poszukiwanych informacji i możliwości jego zastosowania w badaniach socjologicznych. Przegląd Socjologiczny, 30, 54-68.

Rogers E.M. (1983). Diffusion of Innovations. Wyd. 3. USA: Macmillan Publishing. 
Rymsza A. (2012). Zagubiona tożsamość. Analiza porównawcza sektora pozarządowego w Polsce i w Stanach Zjednoczonych. Warszawa: Ministerstwo Pracy i Polityki Społecznej.

Sørensen E., Torfing J. (2015). Enhancing public innovation through collaboration, leadership and new public governance. W: A. Nicholls, J. Simon, M. Gabriel (red.). New Frontiers in Social Innovation Research (s. 145-169). UK: Palgrave Macmillan.

Strategia Polityki Społecznej Województwa Lubelskiego na lata 2014-2020 (2013). Lublin: Regionalny Ośrodek Polityki Społecznej w Lublinie.

The Young Foundation (2012). Social Innovation Overview: A deliverable of the project: "The theoretical, empirical and policy foundations for building social innovation in Europe" (TEPSIE). European Commission - 7th Framework Programme, Brussels: European Commission, DG Research.

Zajda K., Sykała Ł., Janas K., Dej M. (2016). Metody i instrumenty rozwoju lokalnego. LEADER, RLKS, innowacje społeczne. Łódź: Wydawnictwo Uniwersytetu Łódzkiego.

\title{
Social Innovation Implementation by Rural Non-Governmental Organizations
}

\begin{abstract}
The operation of local social policy entities inevitably involves looking for solutions to social problems. Measures aimed at solving social problems may be atypical, nonstandard, or alternative to what had previously been done in the locality. Social innovations understood this way are introduced by entities from different sectors. Each of them has its characteristics that may facilitate or hamper the process of implementation. The aim of the article is to answer the following questions: 1 . What social problems are discerned by nongovernmental organizations operating in rural gminas of a province where social problems experienced by its residents are particularly numerous? 2. What kind of social problems do they try to reduce? 3. Do they introduce social innovations? If so, then 4 . What kind of social innovations do they introduce? These questions are answered on the basis of results of empirical sociological research carried out in 2016 by applying a) the technique of unstructured interview with a standardized list of information to find, and b) the technique of in-depth unstructured interview on a sample of respectively 108 and 4 nongovernmental organizations from rural gminas of Lubelskie Province. These organizations divide social problems into problems which should be solved/reduced by public institutions, and problems which they can deal with by themselves. They very rarely try to solve problems that source literature identifies as crucial for the prevention of marginalization of rural areas (such as depopulation, poverty and unemployment). About 3\% of the investigated organizations mostly introduce social innovations involving the provision of individualized services. Such innovations are usually short-term, which limits their potential for reducing social problems.
\end{abstract}

Keywords: social innovations, non-governmental organizations, rural areas, social problems. 